\title{
Riverbank filtration for the treatment of highly turbid Colombian rivers
}

\author{
Juan Pablo Gutiérrez ${ }^{1,2}$, Doris van Halem ${ }^{1}$, and Luuk Rietveld ${ }^{1}$ \\ ${ }^{1}$ Civil Engineering Department, Delft University of Technology, Delft, 2628 CN, the Netherlands \\ ${ }^{2}$ Cinara Institute, Faculty of Engineering, 760032 Cali, Colombia \\ Correspondence to: Juan Pablo Gutiérrez (j.p.gutierrezmarin@tudelft.nl, \\ juan.p.gutierrez@correounivalle.edu.co)
}

Received: 21 February 2017 - Discussion started: 23 February 2017

Accepted: 20 April 2017 - Published: 11 May 2017

\begin{abstract}
The poor quality of many Colombian surface waters forces us to seek alternative, sustainable treatment solutions with the ability to manage peak pollution events and to guarantee the uninterrupted provision of safe drinking water to the population. This review assesses the potential of using riverbank filtration (RBF) for the highly turbid and contaminated waters in Colombia, emphasizing water quality improvement and the influence of clogging by suspended solids. The suspended sediments may be favorable for the improvement of the water quality, but they may also reduce the production yield capacity. The cake layer must be balanced by scouring in order for an RBF system to be sustainable. The infiltration rate must remain high enough throughout the river-aquifer interface to provide the water quantity needed, and the residence time of the contaminants must be sufficient to ensure adequate water quality. In general, RBF seems to be a technology appropriate for use in highly turbid and contaminated surface rivers in Colombia, where improvements are expected due to the removal of turbidity, pathogens and to a lesser extent inorganics, organic matter and micro-pollutants. RBF has the potential to mitigate shock loads, thus leading to the prevention of shutdowns of surface water treatment plants. In addition, RBF, as an alternative pretreatment step, may provide an important reduction in chemical consumption, considerably simplifying the operation of the existing treatment processes. However, clogging and self-cleansing issues must be studied deeper in the context of these highly turbid waters to evaluate the potential loss of abstraction capacity yield as well as the development of different redox zones for efficient contaminant removal.
\end{abstract}

\section{Introduction}

Riverbank filtration (RBF) is a water abstraction technology that consists of production wells that extract water some distance away from a surface water body (Fig. 1). As the production wells pump water from the aquifer, surface water flows underground to recharge it, while the subsurface sediments function as a natural filter that removes several contaminants, producing higher quality water than the raw source water (Schubert, 2003; Sontheimer, 1980; Tyagi et al., 2013). In addition, the naturally present groundwater contributes to the higher water quality extracted from RBF systems, e.g., through attenuation (Kuehn and Mueller, 2000) and the change in redox conditions (Bourg, 1992; Hiscock and Grischek, 2002).

The well configuration in RBF systems can be either vertical or horizontal, offering different benefits. Vertical wells are commonly used for longer residence or travel times to ensure higher removal efficiencies of more mobile contaminants. Horizontal wells are usually applied to obtain higher water flows, but they may be unfavorable for the quality of the water abstracted due to shorter residence times (Hunt et al., 2003; Ray, 2002b).

Many variables influence the performance of RBF systems, including riverbed media composition and the hydraulic connectivity of the aquifer (Hubbs et al., 2007; Hunt et al., 2003; Schubert, 2002). In Europe and the United 


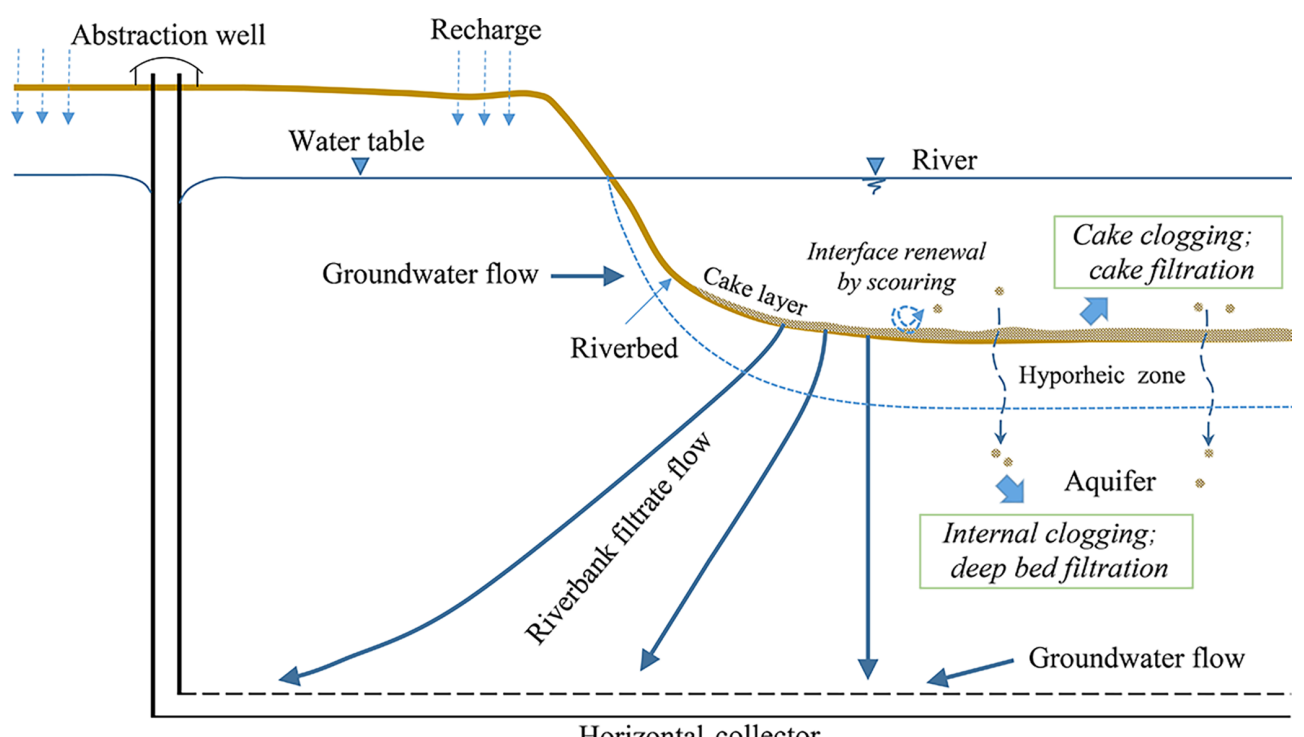

Figure 1. A general representation of a horizontal RBF system.

States, RBF has been widely used because of the favorable hydraulic conditions (Brunke, 1999; Goldschneider et al., 2007; Hubbs et al., 2007; Stuyfzand et al., 2006; Veličković, 2005). In addition, RBF has a demonstrated ability to be an effective water treatment technology for contaminated surface waters (Singh et al., 2010; Thakur and Ojha, 2010).

A key water quality parameter determining the performance of RBF systems is the concentration of total suspended solids (TSS) contained in the surface water; this is because long-term changes in the composition and concentration of suspended solids can have potential cumulative effects on the clogging of riverbanks and alluvial aquifers. In addition, suspended solids generally act as the primary transport mechanism for emerging organisms and pollutants (Bourg et al., 1989; Miretzky et al., 2005; Stone and Droppo, 1994; Zhu et al., 2005). Turbidity is one of the parameters used to indirectly describe the concentration of suspended solids (EPA, 1999), which can be conveniently measured due to the strong relationship between the two parameters (Susfalk et al., 2008; Wu et al., 2014) and the relatively long analysis time of TSS compared to turbidity analysis (Susfalk et al., 2008).

RBF has the additional advantage of removing or attenuating certain heavy metals (Bourg and Bertin, 1993; Stuyfzand, 1998), pathogens (Dillon et al., 2002; Schijven et al., 2003; Schmidt et al., 2003; Sprenger et al., 2014; Weiss et al., 2005) and nutrients (Krause et al., 2013; Ray, 2002b; Schmidt et al., 2003; Wu et al., 2007). In addition, RBF has demonstrated an ability to decrease mutagenic compounds, including naproxen, gemfibrozil and ibuprofen (Hoppe-Jones et al., 2010; Schubert, 2003), and to remove organic and inorganic micro-pollutants, such as sulfamethoxazole and propranolol (Bertelkamp et al., 2014; Hamann et al., 2016; Schmidt et al., 2003). However, it has also been found that specific micro-pollutants such as carbamazepine and EDTA remain mobile, showing persistent behavior even after 3.6 years of travel time (Hamann et al., 2016). The persistence is mainly driven by the very low reactive and sorptive characteristics of these compounds (Scheytt et al., 2006). RBF has also shown the capacity to mitigate shock loads (Mälzer et al., 2003; Schmidt et al., 2003), resulting in a stable abstracted water quality.

Although RBF has been shown to be highly effective in the removal of many contaminants, it must mainly be considered as a pretreatment method that needs to be combined with a certain posttreatment (Cady et al., 2013; Dash et al., 2008; Kuehn and Mueller, 2000; Singh et al., 2010). A balance between the water quality and the production capacity must be considered; greater removal efficiencies are achieved by increasing travel distances, but this can decrease the rate of productivity.

Surface water bodies are the main sources of drinking water for the Colombian communities and make up approximately $80 \%$ of the systems (Ministerio de Desarrollo de Colombia, 1998). However, in the last decades, turbidity and contamination events in surface waters have become a serious concern in Colombia in the context of guaranteeing safe drinking water (Gutiérrez et al., 2016; Universidad del Valle and UNESCO-IHE, 2008). Fast urbanization, the lack of integration between water management and spatial planning and inappropriate land use are identified as the main causes for the progressive deterioration of the surface water (IDEAM, 2015; van der Kerk, 2011; Universidad del Valle and UNESCO-IHE, 2008). Figure 2 illustrates the variation in monthly turbidity percentiles in the Cauca River (Cali, Colombia) for the years 2008-2013 (EMCALI; J. C. Esco- 


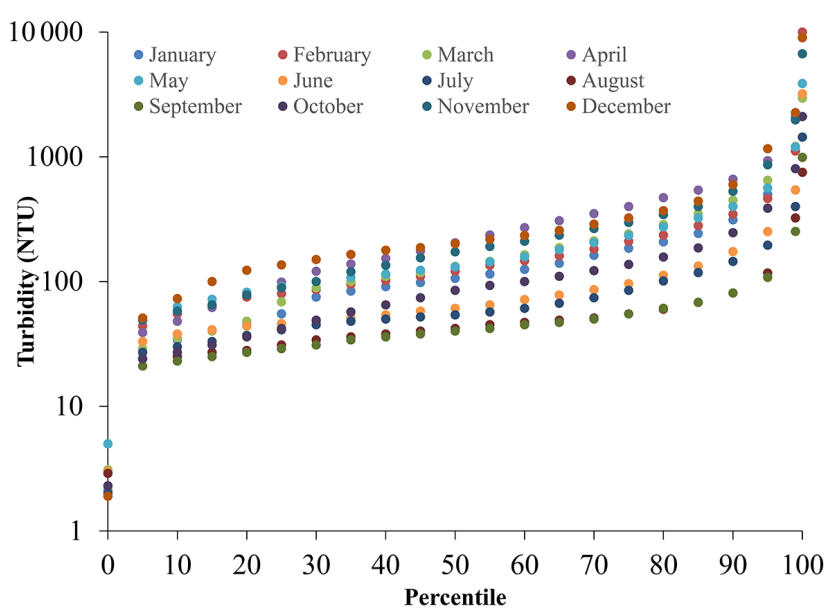

Figure 2. Turbidity percentile values in the Cauca River in Colombia during the years 2008-2013.

bar, personal communication, 2015). High turbidity events in the Cauca River lead to intake shutdowns in the main water treatment plant (Puerto Mallarino WTP) in the city of Cali, where turbidity peaks of up to 10000 NTU (Fig. 2) have been reported. The decrease in the dissolved oxygen concentrations in the Cauca River is used as an indicator of high pollution peaks. It typically drops after heavy rainfalls with the increase in organic matter concentrations (CVC and Universidad del Valle, 2004).

The Pacific basins of Colombia have sediment yields between 1150 and $1714 \mathrm{t} \mathrm{km}^{-2} \mathrm{yr}^{-1}$ (Restrepo and Kjerfve, 2004), while the Magdalena River in the Magdalena-Cauca basin, which corresponds to the most populated zone in the country, has the highest sediment yield $\left(560 \mathrm{t} \mathrm{km}^{-2} \mathrm{yr}^{-1}\right)$ of the large rivers in the Caribbean and on the Atlantic coast of South America; this is similar to the yields found in the larger basins of southern Asian rivers (Restrepo et al., 2009). In addition, significant loads of heavy metals (up to $122 \mathrm{~kg} \mathrm{~d}^{-1} \mathrm{Hg} ; 2600 \mathrm{~kg} \mathrm{~d}^{-1} \mathrm{~Pb} ; 3300 \mathrm{k} \mathrm{d}^{-1} \mathrm{Cd}$; $490 \mathrm{~kg} \mathrm{~d}^{-1} \mathrm{Cr}$ ) and nutrients (up to $1138000 \mathrm{~kg} \mathrm{~d}^{-1} \mathrm{~N}$ and $769000 \mathrm{~kg} \mathrm{~d}^{-1} \mathrm{P}$ ) have been found in the sediments of the Magdalena River (IDEAM, 2011).

Considering the poor quality of many Colombian surface waters, there is a need to seek alternative, sustainable treatment solutions with the ability to manage peak pollution events and to guarantee the uninterrupted provision of safe drinking water to the population. RBF has been shown to be effective in the removal of many river water pollutants and can therefore also be of interest for drinking water companies and environmental and public health authorities in Colombia (Hülshoff et al., 2009; Schijven et al., 2003; Schmidt et al., 2003; Schubert, 2003).

The few reported experiences with RBF in highly turbid and contaminated surface waters led to this review to assess the potential of using RBF for the highly turbid waters in
Colombia by emphasizing water quality improvement and the influence of clogging by suspended solids.

\section{Water quality improvement}

\subsection{Mechanisms of water quality improvement in RBF systems}

RBF removes contaminants through filtration, sorption of pollutants to soil particles, microbial degradation, chemical precipitation, ion exchange and oxidation and reduction (Schmidt et al., 2003; Schubert, 2003). In the first centimeters of the riverbed, a fine sediment layer is formed, also known as a cake layer. The cake layer is called a schmutzdecke if a highly active biological layer is involved (Hiscock and Grischek, 2002; Unger and Collins, 2006). A certain degree of clogging in the riverbed is preferred since it can be favorable for water quality improvement (Ray and Prommer, 2006) due to the augmentation of traveling times, particulate removal and the richness of the processes occurring in the schmutzdecke (Hiscock and Grischek, 2002; Schmidt et al., 2003; Unger and Collins, 2006). Jüttner (1995) determined that the schmutzdecke and the upper layers were responsible for most of the elimination of volatile organic carbon, and Dizer et al. (2004) concluded that this layer is extremely efficient in eliminating viruses. Maeng et al. (2008) found that $50 \%$ of the total dissolved organic matter removal in a simulated RBF system occurred in the first few centimeters of the infiltration surface due to the biological activity in the developed biomass. In the schmutzdecke, the removal of organic matter, pathogens and chemicals occurs through predation, scavenging and metabolic breakdown mechanisms (Haig et al., 2011). A cake layer, mainly composed of organic and/or clay constituents, may also enhance the sorption of pollutants onto its surface (Li et al., 2003).

The interface between the surface water and the groundwater, corresponding to the hyporheic zone (Fig. 1), plays the most important role in the degradation of contaminants (Doussan et al., 1997; Grischek and Ray, 2009; Maeng et al., 2008; Smith et al., 2009; Stuyfzand, 2011). The hyporheic zone is characterized by redox gradients, the dynamic exchange of oxygen and the presence of organic carbon and microorganisms (Doussan et al., 1997; Febria et al., 2012; Findlay and Sobczak, 2000) that enhance electron transfer, ion exchange and degradation and sorption processes, therefore improving the removal of pollutants (Hiscock and Grischek, 2002; Smith, 2005; Tufenkji et al., 2002). Commonly, microbial activity is high in the early stages of infiltration, depleting the oxygen in the hyporheic zone and producing anoxic or anaerobic conditions (Doussan et al., 1997; Krause et al., 2013).

The flow path between the river and the abstraction well is characterized by lower biological activity and sorption capacity as well as longer retention times and increased mix- 
ing (Hiscock and Grischek, 2002; Stuyfzand, 2011). This flow path is therefore of great importance for the removal of poorly degradable pollutants, which require greater distances to be removed or inactivated. In both the hyporheic zone and the flow path, deep bed filtration mechanisms are important.

During deep bed filtration, the particles in suspension to be removed are considerably smaller than the average size of the aquifer pores (Brunke, 1999; Sutherland, 2008; Zamani and Maini, 2009). Therefore, particle separation mainly occurs due to selective straining within the porous media through sedimentation, interception, inertial forces or Brownian motion (Sutherland, 2008). Pathogens are mainly removed from the water through straining, inactivation and attachment to the soil grains (Schijven et al., 2003).

The transformation of nutrients in the subsoil is a function of the exchange rates between the river and hyporheic zone, residence times, dissolved oxygen and biotic processes (Krause et al., 2013; Smith, 2005). The hyporheic zone may have anoxic or anaerobic conditions due to high levels of microbial activity (Doussan et al., 1997; Krause et al., 2013). If the consumption of oxygen exceeds the hydrological oxygen exchange rate, anoxic conditions lead to an oxic-anoxic interface. The reduced and oxidized forms of the nutrients may coexist under such conditions (Duff and Triska, 2000).

The removal of heavy metals from source water during subsurface passage mainly occurs through sorption, precipitation and ion exchange processes, which depend on the content of the inorganic and organic compounds in the aquifer and the contact time (Bourg et al., 1989; Hülshoff et al., 2009). Under aerobic conditions, heavy metal removal is mainly attributed to ion exchange processes at negatively loaded surfaces (Schmidt et al., 2003). The presence of negatively charged surfaces (e.g., clayey and/or organic sediments) and amorphous ferric and aluminum oxides provide exchange sites for binding trace heavy metals (Foster and Charlesworth, 1996; Salomons and Förstner, 1984). As contact time is a critical parameter affecting the fate of most heavy metals, the removal of such compounds through ion exchange processes mainly occurs in the hyporheic zone and the flow path between the river and the abstraction well (Hülshoff et al., 2009; Stuyfzand, 2011). In anoxic aquifers, heavy metals are mainly removed through sorption processes (Schmidt and Brauch, 2008). If the conditions are such that sulfide is formed, the immobilization of heavy metals may occur through sulfide precipitation (Bourg et al., 1989; Salomons and Förstner, 1984).

Micro-pollutants occur in most surface waters that run through heavily polluted regions or large industrial and agricultural areas. The fate of such substances in RBF systems is mainly determined by sorption mechanisms and biological transformations (Schmidt et al., 2003). During absorption, hydrophobic interactions occur between the aliphatic and aromatic groups of micro-pollutants and the membrane cells of the microorganisms. During adsorption, the negatively charged surfaces of the microorganisms and the soil lead to electrostatic interactions of the positively charged micro-pollutants (Luo et al., 2014).

Extensive research in Germany has shown that these compounds may be removed to varying degrees, mainly depending on the properties of each compound (Schmidt et al., 2003). As stated by Schmidt et al. (2004), the biodegradation of organic micro-pollutants is a function of the available organic carbon for energy production. The process of energy production is primarily based on redox reactions. The extent of biodegradation of an organic micro-pollutant is dependent on residence time and favorable redox conditions. Therefore, the elimination rates of certain micro-pollutants vary depending on local geological and hydrochemical conditions and organic loads of surface waters and infiltration zones (Schmidt et al., 2004).

\subsection{Turbidity removal at RBF sites with highly turbid surface waters}

Turbidity removal has been proven to be highly efficient using RBF (Dash et al., 2008, 2010; Ray et al., 2008; Saini et al., 2013; Schubert, 2001; Thakur and Ojha, 2010; Wang, 2003; Wang et al., 1996, 2001; Weiss et al., 2005). Thakur and Ojha (2010) studied the variation in turbidity during the extraction of subsurface water for the supply of drinking water to Haridwar. According to these authors, the river channel (from the Ganges River in Uttarakhand, India) reached turbidity values of up to $2500 \mathrm{NTU}$, and turbidity removals between 99 and $99.9 \%$ were obtained during RBF. In Table 1 , more turbidity removal values are presented from RBF sites with highly turbid surface waters.

The RBF system configuration (i.e., vertical or horizontal) does not govern the suspended solid removal efficiency, as observed in Table 1, since it is not a function of the travel time or the contact time. The texture of the streambed, however, influences the media clogging (Hubbs et al., 2007; Stuyfzand et al., 2006), where external clogging (cake layer formation) enhances the removal capacity of fine sediments contained in the water (Veličković, 2005). The removal efficiency of suspended solids is concentration dependent (Fallah et al., 2012; Thakur and Ojha, 2010); the higher the suspended solid concentration, the faster the cake formation, and therefore the higher the turbidity removal capacity. Although no studies have quantified the role of concentration in entrapment, the critical particle concentration at which the porous media become clogged has been determined to be dependent on the ratio of void size to particle size (Sen and Khilar, 2006). As reported by Sen and Khilar (2006), the critical particle concentration increased from 0.35 to $9 \%$ when the ratio of bead size to particle size was increased from 12 to 40. Therefore, the removal efficiency of suspended solids is a function of both the filtering media characteristics (streambed and particle sizes in the aquifer) and the water quality in terms of suspended particle size and concentration. 
Table 1. Turbidity removal at bank filtration sites with highly turbid raw water sources.

\begin{tabular}{|c|c|c|c|c|c|}
\hline $\begin{array}{l}\text { Bank filtration } \\
\text { site }\end{array}$ & $\begin{array}{l}\text { Pant Dweep Island at } \\
\text { Haridwar, India } \\
\text { (Dash et al., 2010) } \\
\text { (Thakur and Ojha, 2010) }\end{array}$ & $\begin{array}{l}\text { Indiana American } \\
\text { Water at } \\
\text { Jeffersonville, USA } \\
\text { (Weiss et al., 2005) }\end{array}$ & $\begin{array}{l}\text { Indiana American } \\
\text { Water at Terre } \\
\text { Haute, USA } \\
\text { (Weiss et al., 2005) }\end{array}$ & $\begin{array}{l}\text { Missouri American } \\
\text { Water at Parkville, } \\
\text { USA } \\
\text { (Weiss et al., 2005) }\end{array}$ & $\begin{array}{l}\text { Louisville, } \\
\text { Kentucky, } \\
\text { USA } \\
\text { (Wang, 2003) }\end{array}$ \\
\hline $\begin{array}{l}\text { Distance from } \\
\text { source water } \\
\text { V: vertical } \\
\text { H: horizontal }\end{array}$ & $\begin{array}{l}320 \mathrm{~m}(\mathrm{~V}) \\
108 \mathrm{~m}(\mathrm{~V})\end{array}$ & $\begin{array}{l}177 \mathrm{~m}(\mathrm{~V}) \\
30 \mathrm{~m}(\mathrm{~V})\end{array}$ & $\begin{array}{l}24 \mathrm{~m}(\mathrm{H}) \\
122 \mathrm{~m}(\mathrm{~V})\end{array}$ & $\begin{array}{l}37 \mathrm{~m}(\mathrm{~V}) \\
37 \mathrm{~m}(\mathrm{~V})\end{array}$ & $\begin{array}{l}23(\mathrm{~V}) \\
24(\mathrm{H})\end{array}$ \\
\hline Travel time (d) & $\begin{array}{l}420-510 \\
32.5\end{array}$ & $\begin{array}{l}13-19 \\
3-5\end{array}$ & NA & NA & $2-5$ \\
\hline $\begin{array}{l}\text { Source water } \\
\text { (maximum } \\
\text { turbidity; NTU) }\end{array}$ & $\begin{array}{l}200 \\
2500\end{array}$ & 661 & 1761 & 1521 & 599 \\
\hline $\begin{array}{l}\text { Bank filtration } \\
\text { system (maximum } \\
\text { turbidity; NTU) }\end{array}$ & $\begin{array}{l}0.6 \\
\text { Not available }\end{array}$ & $\begin{array}{l}1.1 \\
1.5\end{array}$ & $\begin{array}{l}0.27 \\
0.41\end{array}$ & $\begin{array}{l}3.8 \\
2.7\end{array}$ & $\begin{array}{l} \pm 0.8 \\
0.69\end{array}$ \\
\hline $\begin{array}{l}\text { Turbidity } \\
\text { removal (\%) }\end{array}$ & $\begin{array}{l}99.7 \\
\pm 99.9\end{array}$ & $\begin{array}{l}99.83 \\
99.77\end{array}$ & $\begin{array}{l}99.98 \\
99.98\end{array}$ & $\begin{array}{l}99.75 \\
99.82\end{array}$ & $\begin{array}{l} \pm 99.8 \\
99.88\end{array}$ \\
\hline Aquifer material & $\begin{array}{l}\text { Sand, clayey and } \\
\text { silty sands }\end{array}$ & $\begin{array}{l}\text { Clay, fine and } \\
\text { medium sands, } \\
\text { coarse gravels }\end{array}$ & $\begin{array}{l}\text { Medium and fine } \\
\text { sands underlain } \\
\text { by coarser } \\
\text { sand and gravel }\end{array}$ & $\begin{array}{l}\text { Fine to coarse } \\
\text { sand, gravel } \\
\text { and boulder } \\
\text { deposits with } \\
\text { intermixed } \\
\text { layers of clay } \\
\text { and silt overlying } \\
\text { consolidated shale } \\
\text { and limestone }\end{array}$ & $\begin{array}{l}\text { Sand and } \\
\text { gravel with } \\
\text { silt and clay }\end{array}$ \\
\hline
\end{tabular}

\subsection{Pathogen removal with RBF}

Schijven et al. (2003) showed the efficiency of RBF for microbial contaminant removal, which depends on flow path length and residence times; the longer the flow path and the residence time, the higher the removal. Bacterial removal larger than $2.5 \log$ has been reported in RBF systems with most of the removal occurring in the first meter of filtration (Wang, 2003). Cady et al. (2013) studied an RBF system in the Kali River and achieved removals of $2.7 \mathrm{log}$ for total coliforms and $3.4 \log$ for E. coli ( $1 \log$ for E. coli per $26 \mathrm{~m}$ ). However, Weiss et al. (2015) found that the total coliform reduction at two sites was 5.5 and 6.1 on average.

Virus removal up to $5 \mathrm{log}$ was reported by Sprenger et al. (2014) after only $3.8 \mathrm{~m}$ of RBF passage (approximately 8 days of residence time), demonstrating that RBF is a suitable technology for rivers in emerging countries with regards to virus removal. Derx et al. (2013) found that flooding events significantly alter the removal efficiency of viruses in RBF systems by increasing the advection and dispersion of the viruses through the aquifer system. The virus concentration in the abstraction wells was found to increase up to 8 times due to the decrease in travel times.
Weiss et al. (2005) reported parasite (Cryptosporidium and Giardia) removal at three RBF facilities, where no parasites were detected in the well waters. Metge et al. (2010) studied the parasite (Cryptosporidium parvum) removal efficiency in an RBF system comprised of well-graded, metal-oxide-rich content sediments and found that the main immobilization mechanism was sorption to the metal oxide contents (iron and aluminum).

\subsection{Nutrient removal with RBF}

Doussan et al. (1997) studied the behavior of nitrogen as nitrate, nitrite and ammonium in an RBF system fed by the Seine River. They found a complete removal of nitrate and nitrite, while the ammonium concentrations at the RBF site increased in comparison to the concentration in the river water. Regnery et al. (2015) also found a significant decrease in nitrate concentrations through denitrification. The presence of reducing conditions is commonly found during RBF passage due to the long paths and residence times of the water transported from the river to the RBF abstraction wells. Ammonium concentrations are usually low in surface waters due to the nitrification processes occurring in rivers. However, even 
low ammonium concentrations can cause an extensive oxygen reduction during infiltration (Doussan et al., 1997). By contrast, Wu et al. (2007) reported a decrease in ammonium concentrations and an increase in nitrate and nitrite concentrations in an unsaturated RBF passage, associated with oxic conditions leading to nitrification processes. They reported removals of nitrogen over $95 \%$ through nitrification and denitrification under saturated conditions during the monitoring period. The ammonium concentrations in the river water corresponded to a highly polluted river $\left(16.42 \mathrm{mg} \mathrm{L}^{-1}\right.$; Wu et al., 2007).

Phosphorus is generally removed by sorption and precipitation in the form of calcium, iron or aluminum or iron phosphate (Regnery et al., 2015; Schmidt et al., 2003). Phosphorus removal is influenced by the sedimentary structure of the subsoil (Hendricks and White, 2000). Its sorption is linked to the exchange between the river water and the soil matrix (Hülshoff et al., 2009; Smith, 2005). Leader et al. (2008) assessed the sorption dynamics for different materials and found sorption ranging from 66 to $97 \mathrm{mg}-\mathrm{P} \mathrm{kg}^{-1}$ for clean sand and about $515 \mathrm{mg}-\mathrm{P} \mathrm{kg}^{-1}$ for iron-coated sand. As stated by Vohla et al. (2007), the amount of phosphate that can be removed during subsurface passage is limited to the number of sorption sites, leading to a sorption capacity decrease over time and changes in the physicochemical and oxidation conditions. Regnery et al. (2015) found a decrease in the phosphate removal efficiency in an RBF system from $80 \%$ during start-up to $40 \%$ after 6 years.

\subsection{Heavy metal removal with RBF}

RBF has been shown to be a suitable technology to remove certain heavy metals (Bordas and Bourg, 2001; Bourg et al., 1989; Bourg and Bertin, 1993; Stuyfzand, 1998), although its ability is site and substance specific. As pointed out by Sontheimer (1980), Schmidt et al. (2003) and Stuyfzand et al. (2006), some RBF systems are able to remove heavy metals, such as chromium, and metalloids, like arsenic, by approximately $90 \%$. This is in accordance with experiences in the use of similar technologies, like sand filtration, also resulting in the removal of heavy metals (Awan et al., 2003; Baig et al., 2003; Schmidt and Stadtwerke, 1977). Schmidt et al. (2003) also found lead and cadmium removals of up to $75 \%$ at an RBF site located in Germany with water abstracted from the Rhine River. However, Stuyfzand et al. (2006) found that lead and cadmium concentrations in the abstraction wells increased by over 300 and $30 \%$, respectively, within a 450-day travel time. Bourg et al. (1989) also found that cadmium and zinc were remobilized from sediments, although Bourg and Bertin (1993) still reported zinc removal by riverbank sediments.

\subsection{Micro-pollutant removal with RBF}

Hamann et al. (2016) analyzed the fate of 29 micropollutant compounds in an RBF system considering a travel time of up to 3.6 years and found the complete removal of 14 compounds (2-naphthalene sulfonate, 2,6NDS, amidotrizoic acid, AMPA, aniline, bezafibrate, diclofenac, ibuprofen, iohexol, iomeprol, iopromide, ioxitalamic acid, metoprolol and sulfamethoxazole) due to retardation and degradation processes as supported by numerical modeling. In addition, some compounds were partially removed (triglyme, iopamidol, diglyme, 1,3,5-naphthalene trisulfonate and 1,3,6-naphthalene trisulfonate) with removal efficiencies ranging from approximately 60 to $90 \%$, based on the highest concentrations measured in both the Lek River and the observation well (906 $\mathrm{m}$ from the river; 3.65 years of travel time). Only 10 compounds were fully persistent during the subsurface passage in the RBF system (1,4-dioxane, 1,5-naphthalene disulfonate (1,5-NDS), 2-amino-1,5-NDS, 3-amino-1,5-NDS, AOX, carbamazepine, EDTA, MTBE, toluene and triphenylphosphine oxide). The authors do not differentiate between biodegradation and sorption where adsorption, ion-pair formation and the complexation of pollutants to the soil may lead to soil pollution (Bradl, 2004).

Bertelkamp et al. (2014) assessed the sorption and biodegradation of 14 organic micro-pollutants (acetaminophen, ibuprofen, ketoprofen, gemfibrozil, trimethoprim, caffeine, propranolol, metoprolol, atrazine, carbamazepine, phenytoin, sulfamethoxazole, hydrochlorothiazide and lincomycin) at laboratory scale and found that most of them (the first eight compounds listed above) were completely biodegraded. However, compounds such as atrazine and sulfamethoxazole were not removed in a 6-month period. Schmidt et al. (2003) found that sulfamethoxazole was primarily removed $(20 \%$ removal efficiency) under anaerobic conditions (anaerobic aquifer), while only slightly reduced in the RBF system under aerobic conditions. Drewes et al. (2003) examined the fate of selected pharmaceuticals and personal care products during groundwater recharge; the stimulants caffeine, diclofenac, ibuprofen, ketoprofen, naproxen, fenoproxen and gemfibrozil were efficiently removed. However, the antiepileptics carbamazepine and primidone were not removed at all. Organic iodine was only partially removed. The formation of metabolites may be expected during organic micro-pollutant biodegradation; however, this has not been reported.

Schmidt et al. (2004) studied the fate of anthropogenic organic micro-pollutants comprised of aminopolycarboxylates (EDTA, NTA and DTPA), aromatic sulfonates (2aminonaphthalene-1,5-NDS, 1,3,6-naphthalene trisulfonate, 1,5-NDS, 1- naphthalene sulfonate and 2-naphthalene sulfonate), pharmaceutical compounds (diclofenac, carbamazepine, bezafibrate and sulfamethoxazole), iodinated xray contrast media (iomeprol, amidotrizoic acid and iopamidol) and MTBE. Schmidt et al. (2004) found that sul- 
famethoxazole was primarily removed (20\% removal efficiency) under anaerobic conditions (anaerobic aquifer), while only slightly reduced in the RBF system under aerobic conditions. The reduction in EDTA concentrations under aerobic conditions was higher than that achieved under denitrifying and anaerobic redox conditions. In addition, the EDTA concentrations in the filtrated water were higher than those measured in the surface water; the conclusion is that the DTPA was partially biodegraded, leading to the formation of EDTA as a metabolite (Schmidt et al., 2004).

\section{Clogging and self-cleansing in RBF}

\subsection{Hydraulic conductivity and clogging of the aquifer}

RBF systems worldwide have shown a decline in the longterm yield (Caldwell, 2006; Dash et al., 2010; Hubbs, 2006a; Hubbs et al., 2007; Mucha et al., 2006; Schmidt et al., 2003; Schubert, 2006a; Stuyfzand et al., 2006). The production yield of RBF depends on many factors, including the hydraulic conductivity and the degree of contact between the river and the phreatic aquifer (Caldwell, 2006). Temperature affects the production yield seasonally due to changes in water viscosity (Caldwell, 2006; Hubbs, 2006a); however, this parameter is not a concern in tropical countries like Colombia where the temperature in surface water sources remains largely constant throughout the entire year (Lewis, 2008).

Commonly, hydraulic conductivity varies spatially and can be temporally dependent on clogging and interface renewal through scouring. The clogging layer leads to a reduction in the hydraulic conductivity of the streambed and then affects the hydraulic connectivity between the river and the aquifer. This alters the interaction between the surface water and the groundwater and therefore may influence the abstraction capacity yield (Brunke, 1999; Packman and MacKay, 2003). Nevertheless, the clogging might be favorable for quality improvement due to longer travel times and greater particulate removal, as discussed previously.

Clogging has been identified as the major contributor to the long-term decay of RBF yield (Hubbs et al., 2007), but there is a lack of understanding of the exact factors that affect clogging (Caldwell, 2006; Hubbs et al., 2007; Schubert, 2006a; Stuyfzand et al., 2006). Hubbs et al. (2007) reported a decrease in the specific capacity of the wells of up to $67 \%$ of the initial level in the first 4-year period of operation. Most of the reduction took place within the first year due to riverbed clogging in the vicinity of the well. Clogging is time dependent and is a function of the bed material (Goldschneider et al., 2007; Rehg et al., 2005), the shear forces (Hubbs, 2006b; Schubert, 2006b) scouring out the deposited material on the riverbed (Hubbs, 2006a; Mucha et al., 2006), which are seasonally variable, and the content and composition of the suspended load and the transported bed load material (Bouwer, 2002; Holländer et al., 2005).
Generally, the suspended sediment load carried by the rivers during the rainy season is higher than that found during the dry season (Dunlop et al., 2008; Göransson et al., 2013); however, in regulated river systems, seasonal variations in load do not always follow such a trend (Göransson et al., 2013). Shear forces are also seasonally variable, since these forces are a function of the water level (Hubbs, 2006b). As stated by Regnery et al. (2015), high discharge rates create higher flow velocities and shear stress, which usually results in higher infiltration rates, indicating a lower degree of clogging. By contrast, low discharge rates commonly lead to an increase in pore clogging and then to a lower production yield for an RBF system.

Clogging can be caused by physical, chemical and biological processes, although physical clogging has been found to be the dominant mechanism over the other forms of clogging (Pavelic et al., 2011; Rinck-Pfeiffer et al., 2000). As water flows from the river and through the aquifer to the RBF system, the larger silt particles plug the pore channels to the aquifer in the riverbed and form a less permeable layer together with smaller particles (Grischek and Ray, 2009; Veličković, 2005). Tropical river conditions (temperature and nutrient loads) may be favorable for biological growth onto the riverbed, which might lead to biological clogging (Kim et al., 2010; Platzer and Mauch, 1997; Vandevivere et al., 1995). Rinck-Pfeiffer et al. (2000) reported biological clogging by biomasses and bacterially produced polysaccharides in a simulated aquifer storage and recovery well system; this was related to the high presence of nutrients. Hoffmann and Gunkel (2011) reported severe clogging mainly induced by biological processes in Lake Tegel reaching a depth of at least $10 \mathrm{~cm}$.

As pointed out by Hubbs et al. (2007), medium-coarse sand to fine gravel in the riverbed is desirable, so that little fine sand and silt can penetrate the larger voids in the aquifer; a permanent reduction in the hydraulic conductivity of the aquifer may therefore be avoided. However, Sakthivadivel and Einstein (1970) stated that if the ratio between the bed particle and the suspended particle is larger than 20, clogging of the bed occurs. Also, experiences from the Netherlands have suggested that riverbeds consisting primarily of gravel (up to $25 \mathrm{~cm}$ in size) are at a greater risk of clogging than those consisting primarily of finer-grade materials (Stuyfzand et al., 2006). This is due to the fact that the finer particles will be able to penetrate a greater distance into the gravel riverbed before clogging (Veličković, 2005). Consequently, there is a reduced chance of resuspension or scouring of these particles; the gravel bed acts as a protective shield from flow shear forces, and infiltration rates become permanently impaired (Goldschneider et al., 2007). In sandy and silty riverbeds, the clogging particles cannot penetrate as deeply, and a cake layer will be formed on the riverbed surface (Brunke, 1999; Veličković, 2005). In these instances, flood waves will more easily be able to resuspend and remove the clogging particles, thereby regenerating bed infiltration 
rates to some degree. Levy et al. (2011) estimated a recovery of the hydraulic conductivity by a factor of 1.5 (from 31 to $47 \%$ compared to the hydraulic conductivity of the media before clogging).

Aquifers hydraulically connected to surface waters are susceptible to the long-term accumulation of micro-sized (colloidal) particles (Baveye et al., 1998; Hiscock and Grischek, 2002; Vandevivere et al., 1995), which causes a reduction in the hydraulic conductivity, leading to a reduction in production yield capacity. Hoffmann and Gunkel (2011) reported a decrease in the hydraulic conductivity in a bank filtration system of about 2 orders of magnitude during the winter period. As stated by Hoffmann and Gunkel (2011), the water temperature decrease only amounted to a change in hydraulic conductivity from $4.8 \times 10^{-4}$ to $3.1 \times 10^{-4} \mathrm{~m} \mathrm{~s}^{-1}$. Thus, clogging by micro-sized particles (e.g., particulate organic matter) in combination with atmospheric air intrusion was considered to be the main factor in reducing the hydraulic conductivity. The clogging of the aquifer also depends on the concentration and type of micro-sized particles (Zamani and Maini, 2009). As stated by Okubo and Matsumoto (1983), the concentration should be below $2 \mathrm{mg} \mathrm{L}^{-1}$ to sustain a high infiltration capacity during long inundation periods. In addition, Jacobsen et al. (1997) reported that particles $<10 \mu \mathrm{m}$ are absorbed more strongly at the macropore wall due to their relatively large surface charge, while particles $>10 \mu \mathrm{m}$ are more exposed to hydraulic force.

\subsection{Interface renewal by scouring}

The deposition of sediments carried by river water on the riverbed surface must be balanced by scouring in order for an RBF system to be sustainable. Naturally occurring flow forces may induce sufficient scouring of the riverbed, thereby self-regulating the thickness of the formed cake layer, scouring the bed and restoring its hydraulic conductivity. Scouring is the result of shear stress forces exerted on the riverbed. The extent of scouring is determined by the magnitude of the shear stress and the properties of the riverbed and armor layer deposited onto the riverbed. The shear stress is mainly a function of the fluid velocity and water level at the streambed (Hubbs et al., 2007; Stuyfzand et al., 2006). Shear stress values have been reported to range between 1 and $100 \mathrm{~N} \mathrm{~m}^{-2}$ as typical for river streambeds, considering a value of $20 \mathrm{~N} \mathrm{~m}^{-2}$ as reasonable for the design of an RBF (Hubbs, 2006b). Schubert (2002) estimated an approximate average shear stress of $10 \mathrm{~N} \mathrm{~m}^{-2}$ in the Lower Rhine River region at the Flehe waterworks. Hubbs (2006b) reported a minimum shear stress (during low-flow conditions) of $0.2 \mathrm{~N} \mathrm{~m}^{-2}$ and a maximum shear stress of $9.16 \mathrm{~N} \mathrm{~m}^{-2}$ (during high-flow conditions) in the Ohio River at Louisville, Kentucky. While flood events may stimulate riverbed renewal by streambed scouring as a result of shear forces, lowflow periods may promote the sedimentation of suspended solids at the riverbed (Levy et al., 2011; Stuyfzand et al.,
2006). However, Schubert (2002) stated that flood events might also induce riverbed clogging due to the higher concentration of suspended solids and a higher gradient between the river level and the water table of the aquifer.

The scouring or self-cleansing capacity of RBF systems is commonly assessed in terms of critical shear stress, which depends on riverbed particle characteristics (considering its critical shear stress) and the shear stress exerted by the river water velocity. The viscosity and density of the fluid contribute to shear stress forces (Hubbs et al., 2007), but these properties are expected to be constant in time for tropical rivers (Lewis, 2008). The velocity of the fluid at the streambed is a function of the stream surface slope, water level and resistance to the flow transmitted by the streambed. These parameters vary in time and place, determining the sediment transport capacity on the surface of the streambed (Hubbs et al., 2007).

Erosion and deposition behave dissimilarly for cohesive and non-cohesive sediments (Winterwerp and van Kesteren, 2004). Ahmad et al. (2011) experimentally studied the critical shear stress using sand and different mud mixtures. They found an increase in the critical shear stress by a factor of 1.5 for a mixture with a mud fraction of $50 \%$ in comparison to only sand. For non-cohesive sediments, when the bed shear stress is greater than the critical shear stress, erosion and deposition occur simultaneously (Krishnappan, 2007). By contrast, for cohesive sediments, erosion and deposition do not act simultaneously for all shear stress conditions due to the electrochemical and biological processes binding the cohesive particles to the riverbed. Armor layers made from the deposition of cohesive materials carried by the rivers will increase their resistance to erosive processes, resulting in higher shear stresses to move the sediments deposited on the riverbed. In addition, the shear stress for the deposition of cohesive sediments is different from the shear stress for erosion (Krishnappan, 2007). As stated by Berlamont et al. (1993), the critical shear stress for deposition is usually in the range of $0.05-0.2 \mathrm{~N} \mathrm{~m}^{-2}$, while for erosion it is in the range of $0.1-2 \mathrm{~N} \mathrm{~m}^{-2}$. Moreover, cohesive sediments consolidate over time when deposited on a bed, altering the critical shear stress for erosion through compaction (Krishnappan and Engel, 1994), while their bulk densities tend to increase as a function of depth and time (Lick, 2008). Jepsen et al. (1997) studied the changes in bulk density as a result of depth and consolidation time in the Detroit River, the Fox River and the Santa Barbara slough. Although different bulk densities were obtained among the locations, the density variation trends were similar. Thus, there was an increase in the bulk density by depths of up to $0.2 \% \mathrm{~cm}^{-1}$ in the river sediments and $0.7 \% \mathrm{~cm}^{-1}$ in the slough sediments. Regarding the consolidation time, it increases up to $0.1 \%$ days $^{-1}$ in the river sediments and up to $0.3 \%$ days $^{-1}$ in the slough sediments. Therefore, bed age or consolidation time might play an important role in critical shear stress values and erosion rates for deposited cohesive sediments (Droppo and Amos, 
2001; Jepsen et al., 1997; Krishnappan and Engel, 1994; Stone et al., 2008; Valentine et al., 2014).

\section{Discussion about the applicability of RBF in Colombia}

It may be concluded that RBF is a technology appropriate for use in the highly turbid and contaminated surface rivers in Colombia (Gutiérrez et al., 2016) due to its capacity to remove a high variety of pollutants linked to the influence of the highly suspended sediment loads carried by the rivers. As a consequence of the suspended sediments, cake formation on the riverbed and clogging of the aquifer may occur (Caldwell, 2006), contributing to the removal of most dissolved and suspended contaminants (Ray, 2002a). In addition, good water quality can be obtained at the abstraction wells, requiring only a few additional treatment steps for the production of drinking water (Singh et al., 2010; Sprenger et al., 2014; Thakur and Ojha, 2010).

\subsection{Comparative assessment of water treatment technologies}

In Colombia, conventional surface water treatment plants (involving coagulation, flocculation, sedimentation, filtration and chlorination) are currently used to supply drinking water. As stated by Gutiérrez et al. (2016), in Colombian WTPs the operation, maintenance and sludge disposal are the main processes leading to costly water production. The costs are linked to chemical usage, sludge production and its treatment. The following brief comparison of robust drinking water technologies in the removal of turbidity, pathogens and the chemical contaminants discussed in this review is based on the analysis conducted by Hubbs et al. (2003) and Ray and Jain (2011). Slow sand filtration, with pretreatment, is mainly suitable for small- to medium-sized communities, whereas RBF and conventional WTP can be suitable for small to very large communities (Ray and Jain, 2011). RBF is suitable for highly contaminated rivers, and is able to match conventional treatments, including advanced technologies such as ozone, ultraviolet light and granular-activated carbon, for pesticide removal. Although using a conventional train with the steps coagulation, sedimentation, filtration, activated carbon filtration and disinfection $\left(\mathrm{O}_{3}, \mathrm{UV}, \mathrm{H}_{2} \mathrm{O}_{2}, \mathrm{Cl}_{2}\right)$ and an alternative train with the steps RBF, aeration, filtration, activated carbon filtration and disinfection $\left(\mathrm{O}_{3}, \mathrm{UV}, \mathrm{H}_{2} \mathrm{O}_{2}, \mathrm{Cl}_{2}\right)$ may produce similar water qualities, there are differences in the production costs. The use of RBF leads to savings in chemical dosing, sludge handling and filter backwashing. As reported by Sharma and Amy (2009), the conversion from a conventional WTP to a process including an RBF system may reduce the operational costs by up to $50 \%$. Moreover, the sedimentation step may be skipped, and the advanced removal of pathogens is no longer needed. As reported by Dusseldorp (2013), after anaerobic riverbank filtrate is extracted in a WTP train in the Netherlands, water is pretreated with reverse osmosis prior to the conventional treatment steps of sand filtration, granular-activated carbon and UV disinfection in order to be used in combination with membrane filtration and avoid ultrafiltration and biofouling. RBF has the advantage over the other assessed technologies of dampening shock loads and peaks, which is a need in rivers with extremely variable water qualities, such as the Colombian rivers (e.g., the Cauca River; Fig. 2).

\subsection{Potential challenges in the application of RBF in conventional surface water treatment plants in Colombia}

$\mathrm{RBF}$ as an alternative pretreatment step may provide an important reduction in chemical consumption, considerably simplifying the operation of the existing treatment processes. It is expected that employing RBF in communities where the conditions are appropriate for its implementation (e.g., located in an alluvial formation and close to a river) will lead to considerable improvements in source water quality. Mainly, improvements are expected due to the removal of turbidity, pathogens and to a lesser extent inorganics, organic matter and micro-pollutants. Furthermore, in Colombia, shock loads of pollutants commonly lead to shutdowns of water treatment plants until the peak has passed (Gutiérrez et al., 2016; PérezVidal et al., 2012). RBF has the potential to mitigate shock loads (Schmidt et al., 2003), thus leading to the prevention of shutdowns of water treatment plants.

During the application of RBF in conventional surface WTPs in Colombia, many of the treatment processes currently employed could be varied or even removed completely, leading to simpler plant operation and control. In the specific case of the Puerto Mallarino WTP in Cali, Colombia, RBF would replace all current pretreatment process steps occurring in the grit chamber, the rapid mix chamber and the flocculation and settling clarifiers (Gutiérrez et al., 2016). Chemical doses could be reduced in all remaining processes, but an additional requirement for aeration directly after well extraction may be needed. However, this would only be necessary in the instance that the RBF filtrate had become anaerobic during soil passage. Because of the process changes, a stable inflow quality (turbidity, temperature, $\mathrm{pH}$ and electrical conductivity) means that the plant will operate under more stable conditions, thereby increasing plant efficiency and effluent quality. RBF well operation and control is much simpler than the existing treatment steps, which currently require continual adjustment to ensure smooth plant operation according to any changes in raw water quality. Additionally, a complete reduction in the sludge produced by the grit chambers and clarifiers would be achieved.

$\mathrm{RBF}$ thus typically results in fewer environmental impacts than conventional surface water treatment. The environmental benefits can mainly be attributed to its considerable reductions in chemical usage and sludge production. Likewise, 
the elimination of surface water intake structures may have a positive effect on the surrounding aquatic environment. However, the high sediment loads contained in many Colombian rivers may lead to some negative environmental impacts with the use of RBF, mainly associated with changes in vital aquatic habitats caused by riverbed clogging (Kendy and Bredehoeft, 2007).

The suspended sediments responsible for the clogging processes may, on the one hand, be favorable for the improvement of the water quality, mainly due to the strengthening of cake filtration and deep bed filtration processes. On the other hand, the formed cake layer must be balanced by scouring in order for an RBF system to be sustainable. Therefore, clogging and self-cleansing issues must be studied in greater depth to assess the use of RBF technology in highly turbid waters; they may affect the abstraction capacity yield as well as the development of different redox zones for efficient contaminant removal.

Finally, in the design of an RBF system, a balance between the water quality and the production capacity must be sought. Greater removal efficiencies may be achieved with increased travel distances (residence time), yet there is an inevitable trade-off between the ability to supply large flows and the decreased water quality in the abstraction wells. The longer the travel distance, the higher the fraction of groundwater extracted from storage in the aquifer; therefore, the lower the extraction capacity of the system (de Vet et al., 2010). For an RBF system to be sustainable, the infiltration rate must remain high enough throughout the river-aquifer interface in order to provide the water quantity needed, and the residence time of the contaminants must be sufficient to ensure adequate water quality. Nonetheless, even with shorter residence times, the abstracted water will have better characteristics than the raw water, making further treatment steps such as coagulation, flocculation and sedimentation redundant. Therefore, RBF may be considered a feasible option to address water quality changes at a larger scale.

Data availability. No data sets were used in this article.

Competing interests. The authors declare that they have no conflict of interest.

Acknowledgements. The authors would like to acknowledge the support of Colciencias for the scholarship of Juan Pablo Gutiérrez Marín.

Edited by: B. Mamba

Reviewed by: three anonymous referees

\section{References}

Ahmad, M. F., Dong, P., Mamat, M., Nik, W. B. W., and Mohd, M. H.: The critical shear stresses for sand and mud mixture, Appl. Math. Sci., 5, 53-71, 2011.

Awan, M. A., Qazi, I. A., and Khalid, I.: Removal of heavy metals through adsorption using sand, J. Environ. Sci., 15, 413-416, 2003.

Baig, M. A., Mehmood, B.. and Martin, A.: Removal of chromium from industrial effluents by sand filtration, Electron. J. Environ. Agric. Food Chem., 2, 374-379, 2003.

Baveye, P., Vandevivere, P., Hoyle, B. L., DeLeo, P. C., and Sánchez, D. de L.: Environmental impact and mechanisms of the biological clogging of saturated soils and aquifer materials, Crit. Rev. Environ. Sci. Technol., 28, 1-48, 1998.

Berlamont, J. E., Ockenden, M., Toorman, E. A., and Winterwerp, J. C.: The characterisation of cohesive sediment properties, Coast. Eng., 21, 105-128, 1993.

Bertelkamp, C., Reungoat, J., Cornelissen, E. R., Singhal, N., Reynisson, J., Cabo, A. J., van der Hoek, J. P., and Verliefde, A. R. D.: Sorption and biodegradation of organic micropollutants during river bank filtration: a laboratory column study, Water Res., 52, 231-241, 2014.

Bordas, F. and Bourg, A. C. M.: Effect of solid/liquid ratio on the remobilization of $\mathrm{Cu}, \mathrm{Pb}, \mathrm{Cd}$ and $\mathrm{Zn}$ from polluted river sediment - modeling of the results obtained and determination of association constants between the metals and the sediment, Water. Air. Soil Pollut., 128, 391-400, 2001.

Bourg, A. C. M.: Effet filtre des berges et qualité de l' eau pompée en nappe alluviale, Courants, 14, 32-36, 1992.

Bourg, A. C. M. and Bertin, C.: Biogeochemical processes during the infiltration of river water into an alluvial aquifer, Environ. Sci. Technol., 27, 661-666, 1993.

Bourg, A. C. M., Darmendrail, D., and Ricour, J.: Geochemical filtration of riverbank and migration of heavy metals between the Deûle River and the Ansereuilles alluvion-chalk aquifer (Nord, France), Geoderma, 44, 229-244, 1989.

Bouwer, H.: Artificial recharge of groundwater: hydrogeology and engineering, Hydrogeol. J., 10, 121-142, 2002.

Bradl, H. B.: Adsorption of heavy metal ions on soils and soils constituents, J. Colloid Interface Sci., 277, 1-18, 2004.

Brunke, M.: Colmation and depth filtration within streambeds: retention of particles in hypoheic interstices, Int. Rev. Hydrobiol., 84, 99-117, 1999.

Cady, P., Boving, T. B., Choudri, B. S., Cording, A., Patil, K., and Reddy, V.: Attenuation of bacteria at a riverbank filtration site in rural India, Water Environ. Res., 85, 2164-2174, 2013.

Caldwell, T. G.: Presentation of data for factors significant to yield from several riverbank filtration systems in the U.S. and Europe, in Proceedings of the NATO Advanced Research Workshop on Riverbank Filtration Hydrology: Impacts on System Capacity and Water Quality, edited by: Hubbs, S. A., Bratislava, Slovakia, 299-344, 2006.

CVC and Universidad del Valle: Caracterización río Cauca. Identificación de parámetros críticos en el río Cauca y sus principales ríos tributarios, tramo Salvajina - La Virginia, Corporación Autónoma Regional del Valle del Cauca, CVC. Proyecto de Modelación del Río Cauca - PMC, Fase II. Volumen IX, Cali, Colombia, 2004. 
Dash, R. R., Mehrotra, I., Kumar, P., and Grischek, T.: Lake bank filtration at Nainital, India: water-quality evaluation, Hydrogeol. J., 16, 1089-1099, 2008.

Dash, R. R., Bhanu Prakash, E. V. P., Kumar, P., Mehrotra, I., Sandhu, C., and Grischek, T.: River bank filtration in Haridwar, India: removal of turbidity, organics and bacteria, Hydrogeol. J., 18, 973-983, 2010.

Derx, J., Blaschke, A. P., Farnleitner, A. H., Pang, L., Blöschl, G., and Schijven, J. F.: Effects of fluctuations in river water level on virus removal by bank filtration and aquifer passage - A scenario analysis, J. Contam. Hydrol., 147, 34-44, 2013.

de Vet, W. W. J. M., van Genuchten, C. C. A., van Loosdrecht, M. C. M., and van Dijk, J. C.: Water quality and treatment of river bank filtrate, Drink. Water Eng. Sci., 3, 79-90, doi:10.5194/dwes-379-2010, 2010.

Dillon, P. J., Miller, M., Fallowfield, H., and Hutson, J.: The potential of riverbank filtration for drinking water supplies in relation to microsystin removal in brackish aquifers, J. Hydrol., 266, 209-221, 2002.

Dizer, H., Grützmacher, G., Bartel, H., Wiese, H. B., Szewzyk, R., and López-Pila, J. M.: Contribution of the colmation layer to the elimination of coliphages by slow sand filtration, Water Sci. Technol., 50, 211-214, 2004.

Doussan, C., Poitevin, G., Ledoux, E., and Delay, M.: River bank filtration: modelling of the changes in water chemistry with emphasis on nitrogen species, J. Contam. Hydrol., 25, 129-156, 1997.

Drewes, J. E., Heberer, T., Rauch, T., and Reddersen, K.: Fate of pharmaceuticals during ground water recharge, Gr. Water Monit. Remediat., 23, 64-72, 2003.

Droppo, I. G. and Amos, C. L.: Structure, stability, and transformation of contaminated lacustrine surface fine-grained laminae, J. Sediment. Res., 71, 717-726, 2001.

Duff, J. H. and Triska, F. J.: Nitrogen biogeochemistry and surfacesubsurface exchange in streams, in Streams and Ground Waters, edited by: Jones, J. B. and Mulholland, P. J., Elsevier Inc., Academic Press, 197-220, 2000.

Dunlop, J. E., Kefford, B. J., McNeil, V. H., McGregor, G. B., Choy, S., and Nugegoda, D.: A review of guideline development for suspended solids and salinity in tropical rivers of Queensland, Australia, Australas. J. Ecotoxicol., 14, 129-142, 2008.

Dusseldorp, J.: The effect of pre-treatment with Reverse Osmosis on the biological stability in a drinking water treatment plant, MSc Thesis, Delft University of Technology, 2013.

EPA: Guidance manual for compliance with the interim enhanced surface water treatment rule: turbidity provisions, EPA 815-R99-010, Office of Water, 1999.

Fallah, H., Ahmadi, A., Karaee, M. A., and Rabbani, H.: External cake build up at surface of porous medim, Open J. Fluid Dyn., 2, 145-148, 2012.

Febria, C. M., Beddoes, P., Fulthorpe, R. R., and Williams, D. D.: Bacterial community dynamics in the hyporheic zone of an intermittent stream, ISME J., 6, 1078-1088, 2012.

Findlay, S. and Sobczak, W. V.: Microbial communities in hyporheic sediments, in Streams and Ground Waters, edited by: Jones, J. B. and Mulholland, P. J., Elsevier Inc., Academic Press, 287-306, 2000.
Foster, I. D. L. and Charlesworth, S. M.: Heavy metals in the hydrological cycle: trends and explanation, Hydrol. Process., 10, 227-261, 1996.

Goldschneider, A. A., Haralampides, K. A., and MacQuarrie, K. T. B.: River sediment and flow characteristics near a bank filtration water supply: implications for riverbed clogging, J. Hydrol., 344, 55-69, 2007.

Göransson, G., Larson, M., and Bendz, D.: Variation in turbidity with precipitation and flow in a regulated river system - river Göta Älv, SW Sweden, Hydrol. Earth Syst. Sci., 17, 2529-2542, doi:10.5194/hess-17-2529-2013, 2013.

Grischek, T. and Ray, C.: Bank filtration as managed surface groundwater interaction, Int. J. Water, 5, 125-139, 2009.

Gutiérrez, J. P., Delgado, L. G., van Halem, D., Wessels, P., and Rietveld, L. C.: Multi-criteria analysis applied to the selection of drinking water sources in developing countries: a case study Cali, Colombia, J. Water, Sanit. Hyg. Dev., 6, 401-413, 2016.

Haig, S. J., Collins, G., Davies, R. L., Dorea, C. C., and Quince, C.: Biological aspects of slow sand filtration: past, present and future, Water Sci. Technol. Water Supply, 11, 468-472, 2011.

Hamann, E., Stuyfzand, P. J., Greskowiak, J., Timmer, H., and Massmann, G.: The fate of organic micropollutants during longterm/long-distance river bank filtration, Sci. Total Environ., 545546, 629-640, 2016.

Hendricks, S. P. and White, D. S.: Stream and groundwater influences on phosphorus biogeochemistry, in Streams and Ground Waters, edited by: Jones, J. B. and Mulholland, P. J., 221-235, Elsevier Inc., Academic Press, 2000.

Hiscock, K. M. and Grischek, T.: Attenuation of groundwater pollution by bank filtration, J. Hydrol., 266, 139-144, 2002.

Hoffmann, A. and Gunkel, G.: Bank filtration in the sandy littoral zone of Lake Tegel (Berlin): structure and dynamics of the biological active filter zone and clogging processes, Limnologica, 41, 10-19, 2011.

Holländer, H. M., Hinz, I., Boochs, P. W., and Billib, M.: Experiments to determine clogging and redevelopment effects of ASRwells at laboratory scale resources, in Proceedings of the 5th International Symposium on Management of Aquifer Recharge, ISMAR5, Berlin, Germany, 611-616, 2005.

Hoppe-Jones, C., Oldham, G., and Drewes, J. E.: Attenuation of total organic carbon and unregulated trace organic chemicals in U.S. riverbank filtration systems, Water Res., 44, 4643-4659, 2010.

Hubbs, S. A.: Changes in riverbed hydraulic conductivity and specific capacity at Louisville, in Proceedings of the NATO Advanced Research Workshop on Riverbank Filtration Hydrology: Impacts on System Capacity and Water Quality, edited by: Hubbs, S. A., Bratislava, Slovakia, 199-220, 2006 a.

Hubbs, S. A.: Evaluating streambed forces impacting the capacity of riverbed filtration systems, in Proceedings of the NATO Advanced Research Workshop on Riverbank Filtration Hydrology: Impacts on System Capacity and Water Quality, edited by: Hubbs, S. A., Bratislava, Slovakia, 21-42, 2006 b.

Hubbs, S. A., Hunt, H. C., and Schubert, J.: The costs and benefits of riverbank-filtration systems, in: The Second International Riverbank Filtration Conference, Riverbank Filtration: The Future is Now!, edited by: Melin, G., National Water Research Institute, Cincinnati, Ohio, USA, 16-19 September, 3-6, 2003. 
Hubbs, S. A., Ball, K., and Caldwell, T. G.: Riverbank filtration: an evaluation of RBF hydrology, AwwaRF Report 91141F, 2007.

Hülshoff, I., Greskowiak, J., Wiese, B., and Grützmacher, G.: Relevance and opportunities of bank filtration to provide safe water for developing and newly-industrialised countries, in Combination of MAR and adjusted conventional treatment processes for an Integrated Water Resources Management, TECHNEAU Report D 5.2.9., p. 111, 2009.

Hunt, H., Schubert, J., and Ray, C.: Conceptual design of riverbank filtration systems, in Riverbank Filtration: Improving SourceWater Quality, edited by: Ray, C., Melin, G., and Linsky, R. B., Kluwer Academic Publishers, New York, Boston, Dordrecht, London, Moscow, 61-70, 2003.

IDEAM: Informe del estado del medio ambiente y de los recursos naturales renovables 2010, Bogotá D.C., Colombia, 2011.

IDEAM: Estudio Nacional del Agua 2014, Instituto de Hidrología, Meteorología y Estudios Ambientales de Colombia - IDEAM, Bogotá D.C., Colombia, 2015.

Jacobsen, O. H., Moldrup, P., Larsen, C., Konnerup, L., and Petersen, L. W.: Particle transport in macropores of undisturbed soil columns, J. Hydrol., 196, 185-203, 1997.

Jepsen, R., Roberts, J., and Lick, W.: Effect of bulk density on sediment erosion, Water. Air. Soil Pollut., 99, 21-31, 1997.

Jüttner, F.: Elimination of terpenoid odorous compounds by slow sand and river bank filtration of the Ruhr River, Germany, Water Sci. Technol., 31, 211-217, 1995.

Kendy, E. and Bredehoeft, J.: Mitigating the ecological effects of riverbank filtration, Am. Water Work. Assoc. J., 99, 26-28, 2007.

Kim, J. W., Choi, H., and Pachepsky, Y. A.: Biofilm morphology as related to the porous media clogging, Water Res., 44, 1193-1201, 2010.

Krause, S., Tecklenburg, C., Munz, M., and Naden, E.: Streambed nitrogen cycling beyond the hyporheic zone: Flow controls on horizontal patterns and depth distribution of nitrate and dissolved oxygen in the upwelling groundwater of a lowland river, J. Geophys. Res.-Biogeo., 118, 54-67, 2013.

Krishnappan, B. G.: Recent advances in basic and applied research in cohesive sediment transport in aquatic systems, Can. J. Civ. Eng., 34, 731-743, 2007.

Krishnappan, B. G. and Engel, P.: Critical shear stresses for erosion and deposition of fine suspended sediments in the Fraser River, Environment Canada, Science Division, Research Section, Environmental Conservation Branch, North Vancouver, B.C. V7M 3H7, Burlington, Canada, 1994.

Kuehn, W. and Mueller, U.: Riverbank filtration: an overview, Am. Water Work. Assoc. J., 92, 60-69, 2000.

Leader, J. W., Dunne, E. J., and Reddy, K. R.: Phosphorus sorbing materials: sorption dynamics and physicochemical characteristics, J. Environ. Qual., 37, 174-181, 2008.

Levy, J., Birck, M. D., Mutiti, S., Kilroy, K. C., Windeler, B., Idris, O., and Allen, L. N.: The impact of storm events on a riverbed system and its hydraulic conductivity at a site of induced infiltration, J. Environ. Manage., 92, 1960-1971, 2011.

Lewis Jr., W. M.: Physical and chemical features of tropical flowing waters, in Tropical Stream Ecology, edited by: Dudgeon, D., Elsevier Inc., Academic Press, London, 1, 1-29, 2008.

Li, H., Sheng, G., Teppen, B. J., Johnston, C. T., and Boyd, S. A.: Sorption and desorption of pesticides by clay minerals and humic acid-clay complexes, Soil Sci. Soc. Am. J., 67, 122, 2003.
Lick, W.: Sediment and contaminant transport in surface waters, CRC Press, 2008.

Luo, Y., Guo, W., Ngo, H. H., Nghiem, L. D., Hai, F. I., Zhang, J., Liang, S., and Wang, X. C.: A review on the occurrence of micropollutants in the aquatic environment and their fate and removal during wastewater treatment, Sci. Total Environ., 473474, 619-641, 2014.

Maeng, S. K., Sharma, S. K., Magic-Knezev, A., and Amy, G.: Fate of effluent organic matter (EfOM) and natural organic matter (NOM) through riverbank filtration, Water Sci. Technol., 57, 1999-2007, 2008.

Mälzer, H., Schubert, J., Gimbel, R., and Ray, C.: Effectiveness of riverbank filtration sites to mitigate shock loads, in Riverbank Filtration: Improving Source-Water Quality, edited by: Ray, C., Melin, G., and Linsky, R. B., Kluwer Academic Publishers, New York, Boston, Dordrecht, London, Moscow, 229-259, 2003.

Metge, D. W., Harvey, R. W., Aiken, G. R., Anders, R., Lincoln, G., and Jasperse, J.: Influence of organic carbon loading, sediment associated metal oxide content and sediment grain size distributions upon Cryptosporidium parvum removal during riverbank filtration operations, Sonoma County, CA, Water Res., 44, 11261137, 2010.

Ministerio de Desarrollo de Colombia: Inventario nacional del sector agua potable y saneamiento básico, Tomo I Infraestructura física de los sistemas, Ministerio de Desarrollo Económico, Viceministerio de Desarrollo Urbano, Dirección de Servicios Públicos Domiciliarios, Bogotá D.C., Colombia, 1998.

Miretzky, P., Bisinoti, M. C., and Jardim, W. F.: Sorption of mercury (II) in Amazon soils from column studies, Chemosphere, 60, 1583-1589, 2005.

Mucha, I., Banský, L., Hlavatý, Z., and Rodák, D.: Impact of riverbed clogging - colmatation - on ground water, in Proceedings of the NATO Advanced Research Workshop on Riverbank Filtration Hydrology: Impacts on System Capacity and Water Quality, Bratislava, Slovakia, 43-72, 2006.

Okubo, T. and Matsumoto, J.: Biological clogging of sand and changes of organic constituents during artificial recharge, Water Res., 17, 813-821, 1983.

Packman, A. I. and MacKay, J. S.: Interplay of stream-subsurface exchange, clay particle deposition, and streambed evolution, Water Resour. Res., 39, 1-10, 2003.

Pavelic, P., Dillon, P. J., Mucha, M., Nakai, T., Barry, K. E., and Bestland, E.: Laboratory assessment of factors affecting soil clogging of soil aquifer treatment systems, Water Res., 45, 31533163, 2011.

Pérez-Vidal, A., Delgado-Cabrera, L. G., and Torres-Lozada, P.: Evolución y perspectivas del sistema de abastecimiento de la ciudad de Santiago de Cali frente al aseguramiento de la calidad del agua potable, Ing. y Compet., 14, 69-81, 2012.

Platzer, C. and Mauch, K.: Soil clogging in vertical flow reed beds - mechanisms, parameters, consequences and solutions?, Water Sci. Technol., 35, 175-181, 1997.

Ray, C.: Conclusions and recommendations, in: Proceedings of the NATO Advanced Research Workshop on Riverbank Filtration: Understanding Contaminant Biogeochemistry and Pathogen Removal, edited by: Ray, C., Tihany, Hungary, 247-250, 2002a.

Ray, C.: Effect of biochemical, hydrogeological, and well construction factors on riverbank filtrate quality, in Proceedings of the NATO Advanced Research Workshop on Riverbank Filtration: 
Understanding Contaminant Biogeochemistry and Pathogen Removal, edited by: Ray, C., Tihany, Hungary, 1-16, $2002 \mathrm{~b}$.

Ray, C. and Jain, C. K. (Eds.): Drinking water treatment technology-Comparative analysis, in Drinking Water Treatment, Strategies for Sustainability: Focusing on Appropriate Technology and Sustainability, Springer, 9-36, 2011.

Ray, C. and Prommer, H.: Clogging-induced flow and chemical transport simulation in riverbank filtration systems, in: Proceedings of the NATO Advanced Research Workshop on Riverbank Filtration Hydrology: Impacts on System Capacity and Water Quality, vol. 2, edited by: Hubbs, S. A., Bratislava, Slovakia, 155-177, 2006.

Ray, C., Grischek, T., Hubbs, S. A., Drewes, J. E., Haas, D., and Darnault, C.: Riverbank filtration for drinking water supply, John Wiley \& Sons Ltd., Hoboken, N.J., 2008.

Regnery, J., Barringer, J., Wing, A. D., Hoppe-Jones, C., Teerlink, J., and Drewes, J. E.: Start-up performance of a full-scale riverbank filtration site regarding removal of DOC, nutrients, and trace organic chemicals, Chemosphere, 127, 136-142, 2015.

Rehg, K. J., Packman, A. I., and Ren, J.: Effects of suspended sediment characteristics and bed sediment transport on streambed clogging, Hydrol. Process., 19, 413-427, 2005.

Restrepo, J. D. and Kjerfve, B.: The Pacific and Caribbean rivers of Colombia: water discharge, sediment transport and dissolved loads, in Environmental Geochemistry in Tropical and Subtropical Environments, edited by: de Lacerda, L. D., Santelli, R. E., Duursma, E. K., and Abrão, J. J., Springer Berlin Heidelberg, 169-187, 2004.

Restrepo, J. D., López, S. A., and Restrepo, J. C.: The effects of geomorphic controls on sediment yield in the Andean rivers of Colombia, Lat. Am. J. Sedimentol. Basin Anal., 16, 79-92, 2009.

Rinck-Pfeiffer, S. M., Ragusa, S., Sztajnbok, P., and Vandevelde, T.: Interrelationships between biological, chemical, and physical processes as an analog to clogging in aquifer storage and recovery (ASR) wells, Water Res., 34, 2110-2118, 2000.

Saini, B., Mehrotra, I., Kumar, P., and Verma, R.: Insight of riverbank filtration system at Haridwar for enhancement of drinking water quality, Int. J. Curr. Eng. Technol., 3, 1264-1270, 2013.

Sakthivadivel, R. and Einstein, H. A.: Clogging of porous column of spheres by sediment, J. Hydraul. Div., 96, 461-472, 1970.

Salomons, W. and Förstner, U.: Metals in the hydrocycle, SpringerVerlag Berlin Heidelberg, New York, Tokyo, 1984.

Scheytt, T. J., Mersmann, P., and Heberer, T.: Mobility of pharmaceuticals carbamazepine, diclofenac, ibuprofen, and propyphenazone in miscible-displacement experiments, J. Contam. Hydrol., 83, 53-69, 2006.

Schijven, J., Berger, P., and Miettinen, I.: Removal of pathogens, surrogates, indicators and toxins using riverbank filtration, in Riverbank Filtration: Improving Source-Water Quality, edited by: Ray, C., Melin, G., and Linsky, R. B., Kluwer Academic Publishers, New York, Boston, Dordrecht, London, Moscow, 73116, 2003.

Schmidt, C. K. and Brauch, H. J.: Benefits of riverbank filtration and artificial aquifer recharge: the German experience, in Groundwater Management in Large River Basins, edited by: Dimkić, M., Brauch, H.-J., and Kavanaugh, M., IWA Publishing, Alliance House, 12 Caxton Street, London, 310-332, 2008.

Schmidt, C. K., Lange, F. T., Brauch, H. J., and Kühn, W.: Experiences with riverbank filtration and infiltration in Germany, in Proceedings of the International Symposium of Artificial Recharge of Groundwater, Daejon, Korea, 115-141, 2003.

Schmidt, C. K., Lange, F. T., and Brauch, H. J.: Assessing the impact of different redox conditions and residence times on the fate of organic micropollutants during riverbank filtration, in 4th International Symposium on Pharmaceutically Active Compounds and Endocrine Disrupting Chemicals, 195-205, Minneapolis, Minnesota, 2004.

Schmidt, K. and Stadtwerke, D.: Behavior of special pollutants in slow sand filters used in artificial recharge of groundwater, in Proceedings of the 17th Congress of the International Association for Hydraulic-Research, Baden, Germany, 1977.

Schubert, J.: How does it work? Field studies on riverbank filtration, in Proceedings of the International Riverbank Filtration Conference, Düsseldorf, Germany, 41-55, 2001.

Schubert, J.: Hydraulic aspects of riverbank filtration- - field studies, J. Hydrol., 266, 145-161, 2002.

Schubert, J.: Water quality improvements with riverbank filtration systems at Düsseldorf waterworks in Germany, in Riverbank Filtration: Improving Source-Water Quality, edited by: Ray, C., Melin, G., and Linsky, R. B., Kluwer Academic Publishers, New York, Boston, Dordrecht, London, Moscow, 267-277, 2003.

Schubert, J.: Experience with riverbed clogging along the Rhine River, in Proceedings of the NATO Advanced Research Workshop on Riverbank Filtration Hydrology: Impacts on System Capacity and Water Quality, edited by: Hubbs, S. A., Bratislava, Slovakia, 221-242, 2006a.

Schubert, J.: Significant of hydrologic aspects on RBF performance, in Proceedings of the NATO Advanced Research Workshop on Riverbank Filtration Hydrology: Impacts on System Capacity and Water Quality, edited by: Hubbs, S. A., Bratislava, Slovakia, 1-20, 2006b.

Sen, T. K. and Khilar, K. C.: Review on subsurface colloids and colloid-associated contaminant transport in saturated porous media, Adv. Colloid Interface Sci., 119, 71-96, 2006.

Sharma, S. K. and Amy, G.: Bank filtration: a sustainable water treatment technology for developing countries, in 34th WEDC International Conference, Addis Abada, Ethiopia, p. 5, 2009.

Singh, P., Kumar, P., Mehrotra, I., and Grischek, T.: Impact of riverbank filtration on treatment of polluted river water, J. Environ. Manage., 91, 1055-1062, 2010.

Smith, J. W. N.: Groundwater - surface water interactions in the hyporheic zone, Environment Agency, Science Report SC030155/SR1, Bristol, UK, 2005.

Smith, J. W. N., Surridge, B. W. J., Haxton, T. H., and Lerner, D. N.: Pollutant attenuation at the groundwater-surface water interface: a classification scheme and statistical analysis using nationalscale nitrate data, J. Hydrol., 369, 392-402, 2009.

Sontheimer, H.: Experience with riverbank filtration along Rhine River, Am. Water Work. Assoc. J., 72, 386-390, 1980.

Sprenger, C., Lorenzen, G., Grunert, A., Ronghang, M., Dizer, H., Selinka, H. C., Girones, R., Lopez-Pila, J. M., Mittal, A. K., and Szewzyk, R.: Removal of indigenous coliphages and enteric viruses during riverbank filtration from highly polluted river water in Delhi (India), J. Water Health, 12, 332-342, 2014.

Stone, M. and Droppo, I. G.: In-chanel surficial fine-grained sediment laminae. Part II: Chemical characteristics and implications for contaminant transport in fluvial systems, Hydrol. Process., 8, 113-124, 1994. 
Stone, M., Krishnappan, B. G., and Emelko, M. B.: The effect of bed age and shear stress on the particle morphology of eroded cohesive river sediment in an annular flume, Water Res., 42, 41794187, 2008.

Stuyfzand, P. J.: Fate of pollutants during artificial recharge and bank filtration in the Netherlands, in Proceedings of the 3rd International Symposium on Artificial Recharge of Groundwater TISAR 98, Amsterdam, Netherlands, 119-128, 1998.

Stuyfzand, P. J.: Hydrogeochemical processes during riverbank filtration and artificial recharge of polluted surface waters: zonation, identification, and quantification, in Proceedings of the NATO Advanced Workshop on Riverbank Filtration for Water Security in Desert Countries, edited by: Ray, C. and Shamrukh, M., Luxor, Egypt, 97-128, 2011.

Stuyfzand, P. J., Juhàsz-Holterman, M. H. A., and Lange, W. J.: Riverbank filtration in the Netherlands: well fields, clogging and geochemical reactions, in: Proceedings of the NATO Advanced Research Workshop on Riverbank Filtration Hydrology: Impacts on System Capacity and Water Quality, edited by: Hubbs, S. A., Bratislava, Slovakia, 119-153, 2006.

Susfalk, R. B., Fitzgerald, B. and Knust, A. M.: Suspended solids in the Upper Carson River, Nevada., 2008.

Sutherland, K.: Filtration overview: a closer look at depth filtration, Filtr. Sep., 45, 25-28, 2008.

Thakur, A. K. and Ojha, C. S. P.: Variation of turbidity during subsurface abstraction of river water: a case study, Int. J. Sediment Res., 25, 355-365, 2010.

Tufenkji, N., Ryan, J. N., and Elimelech, M.: The promise of bank filtration: a simple technology may inexpensively clean up poorquality raw surface water, Environ. Sci. Technol., 36, 422A428A, 2002.

Tyagi, S., Dobhal, R., Kimothi, P. C., Adlakha, L. K., Singh, P., and Uniyal, D. P.: Studies of river water quality using river bank filtration in Uttarakhand, India, Water Qual. Expo. Heal., 5, 139$148,2013$.

Unger, M. and Collins, M. R.: Assessing the role of the schmutzdecke in pathogen removal in riverbank and slow sand filtration, in: Recent progress in slow sand and alternative biofiltration processes, edited by: Gimbel, R., Graham, N. J. D., and Collins, M. R., IWA Publishing, Alliance House, 12 Caxton Street, London, London, UK, 21-29, 2006.

Universidad del Valle and UNESCO-IHE: Urban water management for the city of Cali, Diagnosis report: the sewerage system of the city of Cali, Sustainable Water Management Improves Tomorrow's Cities' Health, SWITCH Project, Cali, Colombia, p. 34, 2008.

Valentine, K., Mariotti, G., and Fagherazzi, S.: Repeated erosion of cohesive sediments with biofilms, Adv. Geosci., 39, 9-14, 2014. van der Kerk, A.: Cooperation assessment on water governance Colombia and the Netherlands, Water Governance Centre, Den Haag, the Netherlands, Reference 11-035-P025, 2011.
Vandevivere, P., Baveye, P., and Sánchez, D. de L.: Microbial clogging of saturated soils and aquifer materials: evaluation of mathematical models, Water Resour. Res., 31, 2173-2180, 1995.

Veličković, B.: Colmation as one of the processes in interaction between the groundwater and surface water, Facta Univ. - Ser. Archit. Civ. Eng., 3, 165-172, 2005.

Vohla, C., Alas, R., Nurk, K., Baatz, S., and Mander, Ü.: Dynamics of phosphorus, nitrogen and carbon removal in a horizontal subsurface flow constructed wetland, Sci. Total Environ., 380, 66-74, 2007.

Wang, J.: Riverbank filtration case study at Louisville, Kentucky, in: Riverbank Filtration: Improving Source-Water Quality, edited by: Ray, C., Melin, G., and Linsky, R. B., Kluwer Academic Publishers, New York, Boston, Dordrecht, London, Moscow, 117145, 2003.

Wang, J., Smith, J. W. N., and Dooley, L.: Evaluation of riverbank infiltration as a process for removing particles and DBP precursors, in Proceedings of the Water Quality Technology Conference, American Water Works Association, Denver, CO, USA, New Orleans, LA, USA, 1996.

Wang, J., Song, R., and Hubbs, S. A.: Particle removal through riverbank filtration process, in Proceedings of the International Riverbank Filtration Conference, Düsseldorf, Germany, 127138, 2001.

Weiss, W. J., Bouwer, E. J., Aboytes, R., LeChevallier, M. W., O’Melia, C. R., Le, B. T., and Schwab, K. J.: Riverbank filtration for control of microorganisms: results from field monitoring, Water Res., 39, 1990-2001, 2005.

Winterwerp, J. C. and van Kesteren, W. G. M.: Introduction to the physics of cohesive sediment in the marine environment, Developments in Sedimentology 56, First edit., edited by: van Loon, T., Elsevier, Amsterdam, The Netherlands, 2004.

Wu, J. L., Ho, C. R., Huang, C. C., Srivastav, A. L., Tzeng, J. H., and Lin, Y. T.: Hyperspectral sensing for turbid water quality monitoring in freshwater rivers: empirical relationship between reflectance and turbidity and total solids, Sensors, 14, 2267022688, 2014.

Wu, Y., Hui, L., Wang, H., Li, Y., and Zeng, R.: Effectiveness of riverbank filtration for removal of nitrogen from heavily polluted rivers: a case study of Kuihe River, Xuzhou, Jiangsu, China, Environ. Geol., 52, 19-25, 2007.

Zamani, A. and Maini, B.: Flow of dispersed particles through porous media - deep bed filtration, J. Pet. Sci. Eng., 69, 71-88, 2009.

Zhu, G., Chi, Q., Qin, B., and Wang, W.: Heavy-metal contents in suspended solids of Meiliang Bay, Taihu Lake and its environmental significances, J. Environ. Sci., 17, 672-675, 2005. 